\title{
Dopaminergic profile of new heterocyclic N-phenylpiperazine derivatives
}

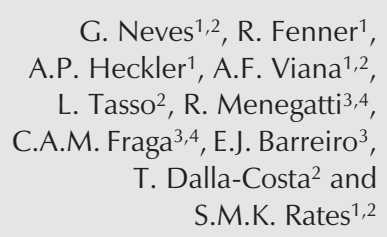

G. Neves ${ }^{1,2}$, R. Fenner ${ }^{1}$, A.P. Heckler ${ }^{1}$, A.F. Viana ${ }^{1,2}$, L. Tasso ${ }^{2}$, R. Menegatti ${ }^{3,4}$, C.A.M. Fraga ${ }^{3,4}$, E.J. Barreiro ${ }^{3}$, T. Dalla-Costa ${ }^{2}$ and S.M.K. Rates ${ }^{1,2}$

\author{
'Laboratório de Psicofarmacologia, Departamento de Produção de Matéria-Prima, \\ Faculdade de Farmácia, and Programa de Pós-Graduação em Ciências Farmacêuticas, \\ Universidade Federal do Rio Grande do Sul, Porto Alegre, RS, Brasil \\ ${ }^{3}$ Laboratório de Avaliação e Síntese de Substâncias Bioativas, Faculdade de Farmácia, \\ and ${ }^{4}$ Instituto de Química, Universidade Federal do Rio de Janeiro, Rio de Janeiro, \\ RJ, Brasil
}

\section{Correspondence}

S.M.K. Rates

Faculdade de Farmácia, UFRGS

Av. Ipiranga, 2752

90610-000 Porto Alegre, RS

Brasil

Fax: +55-51-3316-3417

E-mail: ratessmk@farmacia.ufrgs.br

Presented at the XVII Annual Meeting of the Federação de Sociedades de Biologia Experimental, Salvador, BA, Brazil, August 28-31, 2002.

Research supported by PROCADCAPES.

Received April 18, 2002

Accepted January 8, 2003

\begin{abstract}
Dopamine constitutes about $80 \%$ of the content of central catecholamines and has a crucial role in the etiology of several neuropsychiatric disorders, including Parkinson's disease, depression and schizophrenia. Several dopaminergic drugs are used to treat these pathologies, but many problems are attributed to these therapies. Within this context, the search for new more efficient dopaminergic agents with less adverse effects represents a vast research field. The aim of the present study was to report the structural design of two N-phenylpiperazine derivatives, compound 4: 1-[1-(4-chlorophenyl)- $1 H-4-$ pyrazolylmethyl]-4-phenylhexahydropyrazine and compound $5: 1-[1-$ (4-chlorophenyl)-1 H-1,2,3-triazol-4-ylmethyl]-4-phenylhexahydropyrazine, planned to be dopamine ligands, and their dopaminergic action profile. The two compounds were assayed (dose range of $15-40 \mathrm{mg}$ / $\mathrm{kg}$ ) in three experimental models: 1) blockade of amphetamine (30 $\mathrm{mg} / \mathrm{kg}, i p$ )-induced stereotypy in rats; 2) the catalepsy test in mice, and $3)$ apomorphine $(1 \mathrm{mg} / \mathrm{kg}$, ip)-induced hypothermia in mice. Both derivatives induced cataleptic behavior $(40 \mathrm{mg} / \mathrm{kg}, i p)$ and a hypothermic response $(30 \mathrm{mg} / \mathrm{kg}$, ip) which was not prevented by haloperidol $(0.5 \mathrm{mg} / \mathrm{kg}, i p)$. Compound $5(30 \mathrm{mg} / \mathrm{kg}, i p)$ also presented a synergistic hypothermic effect with apomorphine $(1 \mathrm{mg} / \mathrm{kg}, i p)$. Only compound $4(30 \mathrm{mg} / \mathrm{kg}$, ip) significantly blocked the amphetamine-induced stereotypy in rats. The $\mathrm{N}$-phenylpiperazine derivatives 4 and 5 seem to have a peculiar profile of action on dopaminergic functions. On the basis of the results of catalepsy and amphetamine-induced stereotypy, the compounds demonstrated an inhibitory effect on dopaminergic behaviors. However, their hypothermic effect is compatible with the stimulation of dopaminergic function which seems not to be mediated by $\mathrm{D}_{2} / \mathrm{D}_{3}$ receptors.
\end{abstract}

Key words

- N-phenylpiperazine derivatives

- Dopamine

- Apomorphine hypothermia

- Amphetamine stereotypy

- Catalepsy 
Dopamine belongs to the catecholamine neurotransmitter group and constitutes about $80 \%$ of the content of these substances in the brain. At least five different forms of dopamine receptors have been cloned from the brain. These receptors are divided into two classes: the $\mathrm{D}_{1}$-like class (including $\mathrm{D}_{1}$ and $\mathrm{D}_{5}$ receptors) and the $\mathrm{D}_{2}$-like class (including $\mathrm{D}_{2}, \mathrm{D}_{3}$ and $\mathrm{D}_{4}$ receptors), differentiated by anatomical, pharmacological and biochemical parameters (1).

Dopamine has a crucial role in the etiology of several neuropsychiatric disorders, including Parkinson's disease, depression and, mainly, schizophrenia. Schizophrenia is a chronic psychiatric illness that affects approximately $1 \%$ of the world population. Usually, a schizophrenic patient presents two main kinds of symptoms: positive (delusions, hallucinations) and negative (avolition, anhedonia, attentional impairment) symptoms. Most of the drugs used for treating this disorder are $\mathrm{D}_{2}$-like receptor antagonists and are called typical antipsychotics. These drugs are effective only for treating the positive symptoms and present an important profile

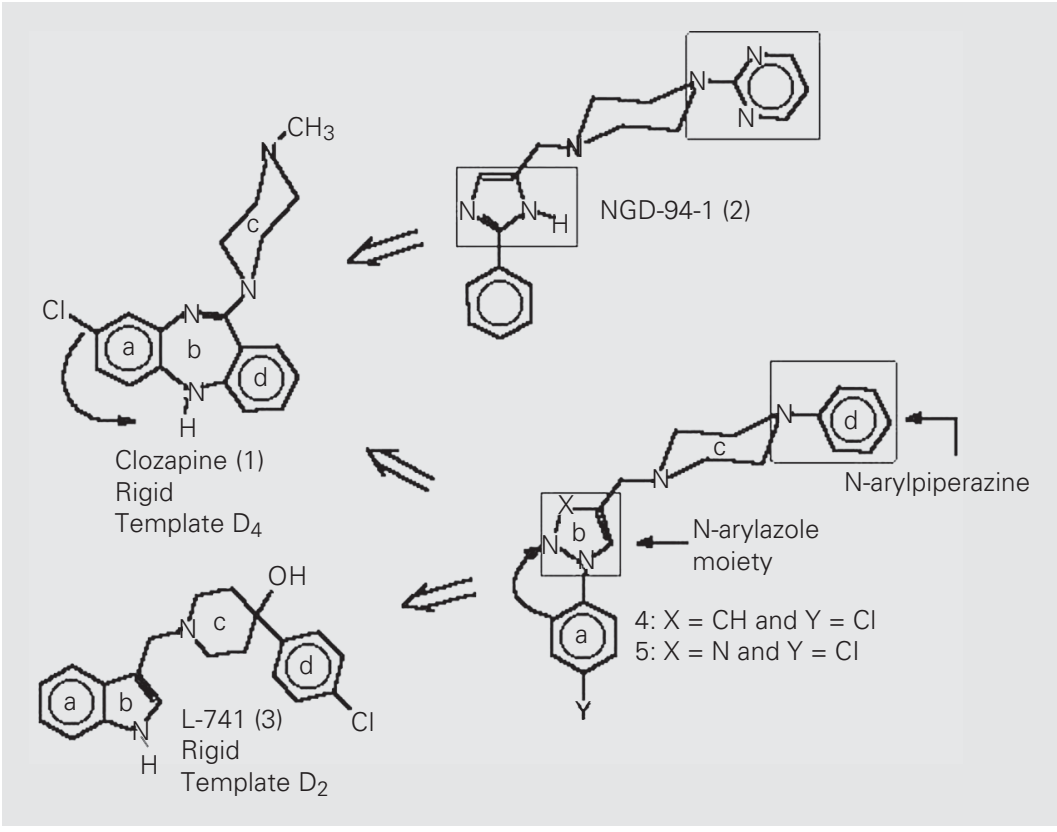

Figure 1. Rational structural design of $\mathrm{N}$-phenylpiperazine derivatives 4 and 5 based on the structure of clozapine (1) and L-741 (3). of adverse effects, mainly the extrapyramidal disturbances such as tardive dyskinesia $(2,3)$.

Clozapine (1) is an atypical antipsychotic drug with high affinity for $\mathrm{D}_{4}$ and $5-\mathrm{HT}_{2}$ receptors that has a pharmacological profile different from that of classic antipsychotics, being effective in the treatment of positive and negative symptoms and lacking the extrapyramidal effects. On the other hand, clozapine (1) tends to induce agranulocytosis in 1 to $2 \%$ of the patients, which restricts its clinical use in patients that do not respond to classical therapy $(2,4)$. For this reason, the search for new more efficient dopaminergic agents with lower adverse effects is still an extremely active research field.

New molecular templates presenting higher functional selectivity for dopamine receptors, such as NGD-94-1 (2) $(\mathrm{Ki}=3.8$ $\left.\mathrm{nM}\left[\mathrm{D}_{4}\right]\right)$ and L-741 (3) $\left(\mathrm{Ki}=2.1 \mathrm{nM}\left[\mathrm{D}_{2}\right]\right)$ have been described $(5,6)$. We have developed new N-phenylpiperazine derivatives with a potential dopaminergic profile by molecular hybridization of the lead compounds clozapine (1) (template $\mathrm{D}_{4}$ ) and L741 (3) (template $D_{2}$ ). The strategy for obtaining the structures of 1-[1-(4-chlorophenyl)-1H-4-pyrazolylmethyl]-4-phenylhexahydropyrazine (compound 4) and isosteric 1-[1-(4-chlorophenyl)-1H-1,2,3triazol-4-ylmethyl]-4-phenylhexahydropyrazine (compound 5) is presented in Figure 1. Both compounds bind to dopamine rat brain receptors (Pereira EFR and Albuquerque EX, unpublished results). In the present study we evaluated the in vivo dopaminergic activity of compounds 4 and 5 in three animal models: blockade of amphetamine-induced stereotypy in rats, the catalepsy test in mice and apomorphine-induced hypothermia in mice.

Male Wistar rats (200 to $250 \mathrm{~g}$ ) and male Swiss CF-1 mice (20 to $30 \mathrm{~g}$ ), both from the breeding colony of Fundação Estadual de Produção e Pesquisa em Saúde (Porto Alegre, RS, Brazil), were used. The animals had free access to food and water and were kept 
at constant room temperature $\left(22 \pm 1^{\circ} \mathrm{C}\right)$ under a 12-h light cycle (lights off at 7:00 pm). All drugs were administered by the intraperitoneal (ip) route (injection volume of $1 \mathrm{ml} / \mathrm{kg}$ rat body weight and $1 \mathrm{ml} / 100 \mathrm{~g}$ mouse body weight). Compounds 4 and 5 were suspended in saline with the aid of no more than $5 \%(\mathrm{v} / \mathrm{v})$ polysorbate 80 . The experimental groups consisted of at least 10 animals each.

Amphetamine-induced stereotypy was evaluated according to the protocol and doses described by Carlini (7). Thirty minutes after amphetamine $(30 \mathrm{mg} / \mathrm{kg}$, ip) administration, the results were scored from 0 to 3 according to increasing intensity of stereotypy (7). This behavior is classically blocked by drugs that inhibit the dopaminergic functions such as neuroleptics ( $\mathrm{D}_{2}$ antagonists) (8). Conversely, atypical antipsychotics like clozapine (1) have little or no effect on stereotypy (9). The results are shown in Table 1. Only compound 4 (30 $\mathrm{mg} / \mathrm{kg}$, ip) significantly blocked the stereotyped behavior, although compound $5(30 \mathrm{mg} /$ $\mathrm{kg}, i p$ ) also showed a tendency to block it.

The induction of catalepsy test was adapted from those described by Carlini (7). The mice were placed gently on a wood bar elevated $6.5 \mathrm{~cm}$ from the floor. The time spent by the animals in this position was measured 30 and 60 min after the treatments. The results are shown in Table 1. Both derivatives induced a time- and dose-dependent cataleptic behavior in the animals. Compound 5 presented a longer-lasting effect, indicating a possible pharmacokinetic difference between drugs. Despite having virtually no strength as an animal behavioral model for antipsychotics, catalepsy tests do have value in the study of neuropharmacology of extrapyramidal function and as a rapid behavioral screening for predicting the motor side effects of potentially antipsychotic drugs $(10,11)$. The extrapyramidal side effects of antipsychotic drugs are related to a blockade of $\mathrm{D}_{2}$ striatal dopamine receptors (12). However, selective $D_{1}$ blockers such as SCH23390 also induce marked catalepsy behavior in animals similar to those of opioids and cholinergic agonists (10).

To test the apomorphine $(1 \mathrm{mg} / \mathrm{kg} i p)$ induced hypothermia, two treatments were administered to each animal: the first one immediately after measuring the basal rectal temperature (T0) and the second one $30 \mathrm{~min}$ later. The rectal temperature was recorded 15 and $30 \mathrm{~min}$ after the second treatment (T45 and T60, respectively) $(9,13)$. The results are shown in Table 2. A single administration of compounds $4(30 \mathrm{mg} / \mathrm{kg}$, ip $)$ and 5 $(30 \mathrm{mg} / \mathrm{kg}$, ip) induced a hypothermic response which was not abolished by haloperidol $(0.5 \mathrm{mg} / \mathrm{kg}$, ip $)$ administration. Furthermore, a synergistic hypothermic effect between apomorphine $(1 \mathrm{mg} / \mathrm{kg}$, ip $)$ and compound 5 was demonstrated.

Production of hypothermia is a major pharmacological effect of apomorphine in animals. It has been demonstrated that, at

Table 1. Effect of compounds 4 and 5 on the induction of catalepsy and blockade of amphetamine $(30 \mathrm{mg} / \mathrm{kg})$-induced stereotypy in rodents.

\begin{tabular}{|c|c|c|c|}
\hline \multirow[t]{2}{*}{ Treatment } & \multicolumn{2}{|c|}{ Induction of catalepsy } & \multirow{2}{*}{$\begin{array}{c}\text { Amphetamine } \\
\text { stereotypyc (grades) }\end{array}$} \\
\hline & $30 \min ^{a}$ (s) & $60 \min ^{b}(s)$ & \\
\hline $\begin{array}{l}\text { SAL } \\
\mathrm{C} 4(\mathrm{mg} / \mathrm{kg})\end{array}$ & $1.0(0.7-2.8)$ & $2.9(1.1-5.1)$ & $2.0(2.0-2.0)$ \\
\hline 15.0 & $4.1(1.6-8.8)$ & $13.0(4.6-16.6)$ & NT \\
\hline 20.0 & $4.2(2.9-10.8)$ & $20.6(9.0-24.7)$ & NT \\
\hline 30.0 & 8.5 (2.0-29.9) & $15.8(4.7-33.3)$ & $1.0(1.0-1.0)^{*}$ \\
\hline 40.0 & $16.7(7.5-34.0)^{*}$ & $19.7(6.3-30.3)$ & NT \\
\hline \multicolumn{4}{|l|}{ C5 (mg/kg) } \\
\hline 15.0 & $4.3(2.4-15.5)$ & $15.2(7.9-33.1)$ & NT \\
\hline 20.0 & $4.3(3.0-22.5)$ & $23.3(9.3-26.7)^{*}$ & NT \\
\hline 30.0 & $8.0(5.5-13.6)^{*}$ & $17.8(10.8-23.4)^{*}$ & $1.0(1.0-2.0)$ \\
\hline 40.0 & $16.4(9.4-23.2)^{*}$ & $29.6(15.1-73.8)^{*}$ & NT \\
\hline \multicolumn{4}{|l|}{$\mathrm{HAL}(\mathrm{mg} / \mathrm{kg})$} \\
\hline 0.5 & NT & NT & $0.5(0.0-2.0)^{*}$ \\
\hline 4.0 & $26.8(11.9-77.0)^{*}$ & $70.9(45.7-120.0)^{*}$ & NT \\
\hline
\end{tabular}

The treatments were SAL (saline + polysorbate 80 up to $5 \%, 1.0 \mathrm{ml} / 100 \mathrm{~g}$ mouse body weight, $1.0 \mathrm{ml} / \mathrm{kg}$ rat body weight), C4 (compound 4), C5 (compound 5) and HAL (haloperidol) at the doses indicated. The data are reported as medians and interquartile intervals. NT = not tested.

${ }^{*} P<0.005$ compared to the negative control group (SAL). The letters refer to the columns $30 \mathrm{~min}, 60 \mathrm{~min}$ and amphetamine stereotypy, respectively: a) $\mathrm{H}=35.66$, $\mathrm{P}<0.001$; b) $\mathrm{H}=39.88, \mathrm{P}<0.001$; c) $\mathrm{H}=13.94$, $\mathrm{P}=0.003$; Kruskal-Wallis test 
low doses $(1 \mathrm{mg} / \mathrm{kg})$, this effect results from the direct agonistic action of apomorphine on both $\mathrm{D}_{1}$ and $\mathrm{D}_{2}$ dopamine receptors located in the temperature-regulating centers of the hypothalamus (13-15). Functional interaction between $D_{1}$ and $D_{2}$ receptors has been well documented and these receptors are generally considered to interact synergistically. Nevertheless, there is also evidence for independent roles of dopamine $D_{1}$ and $\mathrm{D}_{2}$ receptors in thermoregulation $(14,16)$. On the other hand, the role of serotonin receptors in thermoregulation should also be considered (17).
At the tested dose, haloperidol efficiently blocked the apomorphine effect on the core temperature of the animals. In contrast, it has been reported that higher doses of haloperidol induce a hypothermic response which is antagonized by the administration of 5- $\mathrm{HT}_{2}$ agonists (18). Thus, since haloperidol did not affect the N-phenylpiperazine derivative-induced hypothermia, it is plausible to suggest that the mechanism of the hypothermic effect of compounds 4 and 5 is other than dopamine $\mathrm{D}_{2} / \mathrm{D}_{3}$ receptor activation. A hypothermic effect that was not abolished by a selective $D_{2}$ antagonist was also reported

Table 2. Effect of compounds 4 and 5 on the rectal temperature of mice.

\begin{tabular}{|c|c|c|c|c|}
\hline \multicolumn{2}{|c|}{ Treatments } & \multirow[t]{2}{*}{ T0 } & \multirow[t]{2}{*}{ T45 } & \multirow[t]{2}{*}{ T60 } \\
\hline 1st treatment & 2nd treatment & & & \\
\hline \multicolumn{5}{|l|}{ Single drug effect ${ }^{a}$} \\
\hline SAL & SAL & $38.2 \pm 0.4$ & $38.0 \pm 0.8$ & $38.2 \pm 0.7$ \\
\hline $\mathrm{C} 4$ & SAL & $38.3 \pm 0.5$ & $36.1 \pm 0.9 * \S$ & $36.5 \pm 1.1 * \S$ \\
\hline $\mathrm{C} 5$ & SAL & $37.9 \pm 0.4$ & $35.7 \pm 1.2 * \S$ & $35.7 \pm 1.3 * \S$ \\
\hline APO & SAL & $38.3 \pm 0.4$ & $37.2 \pm 0.6^{* \S}$ & $37.4 \pm 0.6^{* \S}$ \\
\hline HAL & SAL & $38.4 \pm 0.3$ & $38.1 \pm 0.3$ & $38.1 \pm 0.3$ \\
\hline \multicolumn{5}{|c|}{ Effect on apomorphine-induced hypothermiab } \\
\hline SAL & SAL & $38.2 \pm 0.4$ & $38.0 \pm 0.8$ & $38.2 \pm 0.7$ \\
\hline SAL & APO & $38.0 \pm 0.5$ & $35.9 \pm 1.3 * \S$ & $35.7 \pm 1.5^{* \S}$ \\
\hline $\mathrm{C} 4$ & APO & $38.4 \pm 0.3$ & $35.9 \pm 1.4 * \S$ & $36.5 \pm 1.2^{* \S}$ \\
\hline $\mathrm{C} 5$ & APO & $38.1 \pm 0.6$ & $34.4 \pm 1.3^{* \# \S}$ & $34.3 \pm 1.8^{* \# \S}$ \\
\hline $\mathrm{HAL}$ & APO & $38.4 \pm 0.6$ & $37.6 \pm 0.6^{\# \S}$ & $37.7 \pm 0.7^{\# \S}$ \\
\hline \multicolumn{5}{|c|}{ Haloperidol blockade of hypothermiac } \\
\hline SAL & SAL & $38.2 \pm 0.4$ & $38.0 \pm 0.8$ & $38.2 \pm 0.7$ \\
\hline HAL & SAL & $38.4 \pm 0.3$ & $38.1 \pm 0.3$ & $38.1 \pm 0.3$ \\
\hline SAL & $\mathrm{C} 4$ & $38.0 \pm 0.5$ & $37.1 \pm 0.6^{* \S}$ & $36.5 \pm 0.8^{*+}$ \\
\hline $\mathrm{HAL}$ & C4 & $38.3 \pm 0.6$ & $36.8 \pm 0.5^{* \S}$ & $36.6 \pm 0.7^{* \S}$ \\
\hline SAL & $\mathrm{C} 5$ & $38.1 \pm 0.3$ & $36.5 \pm 0.6^{* \S}$ & $35.9 \pm 0.7^{*+}$ \\
\hline $\mathrm{HAL}$ & $\mathrm{C} 5$ & $38.5 \pm 0.3$ & $36.7 \pm 0.7^{* \S}$ & $36.1 \pm 0.9^{*+}$ \\
\hline
\end{tabular}

The treatments were SAL (saline + polysorbate 80 up to $5 \%, 1.0 \mathrm{ml} / 100 \mathrm{~g}$ mouse body weight), APO (apomorphine, $1.0 \mathrm{mg} / \mathrm{kg}$ ), HAL (haloperidol, $0.5 \mathrm{mg} / \mathrm{kg}$ ), C4 (compound 4, $30.0 \mathrm{mg} / \mathrm{kg}$ ), and C5 (compound 5 , $30.0 \mathrm{mg} / \mathrm{kg}$ ). T0 is the basal temperature of the animals before any treatment, T45 the rectal temperature 15 min after the second treatment, and T60 the rectal temperature 30 min after the second treatment. The interval between treatments was $30 \mathrm{~min}$. Data are reported as means $\pm \mathrm{SD}$ in ${ }^{\circ} \mathrm{C}$

${ }^{*} \mathrm{P}<0.05$ compared to the control group (SAL + SAL) at the same time.

${ }^{\#} \mathrm{P}<0.05$ compared to the apomorphine group (SAL + APO) at the same time point.

${ }^{\S} \mathrm{P}<0.05$ compared to the T0 measure in the same group.

+Statistically different from T0 and T45 measures in the same group.

Two-way repeated measures ANOVA followed by the Student-Newman-Keuls post hoc test: a) treatments: $F_{4,197}=20.56, P<0.001$; time: $F_{2,197}=103.02, P<0.001$; time $x$ treatment: $\left.F_{8,197}=14.92, P<0.001 ; b\right)$ treatments: $F_{4,182}=19.52, P<0.001$; time: $F_{2,182}=123.91, P<0.001$; time $x$ treatment: $F_{8,182}=15.43$, $P<0.001$; c) treatments: $F_{5,248}=20.71, P<0.001$; time: $F_{2,248}=193.09, P<0.001$; time $x$ treatment: $F_{10,248}=$ $15.01, P<0.001$ 
for the selective $\mathrm{D}_{1}$ agonist A68930 (14). In addition, it was reported that clozapine (1)induced hypothermia in rats is blockaded by selective $D_{1}$ antagonists, suggesting that this drug may be a partial $\mathrm{D}_{1}$ agonist $(19,20)$. On the other hand, Menon et al. (15) demonstrated that the selective $D_{1}$ antagonist SCH23390 was not effective in blocking the apomorphine-induced hypothermia but caused a potentiation of the hypothermic effect of quinpirole, a selective $\mathrm{D}_{2}$ agonist. Since compounds 4 and 5 were planned based on the chemical structure of clozapine, it is possible that their hypothermic effects are also mediated by $\mathrm{D}_{1}$ receptor occupation or, perhaps, by interaction with the serotonergic system. The hypothermic effects of compounds 4 and 5 have a magnitude comparable to that of subcutaneous $10 \mathrm{mg} / \mathrm{kg}$ clozapine in rats (20). Other experiments are in progress to elucidate the putative participation of $\mathrm{D}_{1}$ and $5-\mathrm{HT}_{2}$ receptors in the hypothermic effect of $\mathrm{N}$-phenylpiperazine derivatives.

In conclusion, the N-phenylpiperazine derivatives 4 and 5 seem to have a peculiar profile of action on dopaminergic functions. On the basis of the results of catalepsy and amphetamine-induced stereotypy, the compounds demonstrated an inhibitory effect on dopaminergic behaviors. However, their hypothermic effect is compatible with the stimulation of dopaminergic function which seems not to be mediated by $D_{2} / D_{3}$ receptors.

\section{References}

1. Vallone D, Picetti R \& Borrelli E (2000). Structure and function of dopamine receptors. Neuroscience and Biobehavioral Reviews, 24: 125-132.

2. Baldessarini RJ (1996). Drugs and the treatment of psychiatric disorders: Psychosis and anxiety. In: Hardman JG \& Limbird LE (Editors), Goodman \& Gilman's - The Pharmacological Basis of Therapeutics. 9th edn. McGraw-Hill, New York, NY, USA.

3. Stahl P (2000). Essential Psychopharmacology - Neuroscientific Basis and Practical Applications. 2nd edn. Cambridge University Press, New York, NY, USA.

4. Crismon ML \& Dorson PG (1997). Schizophrenia. In: DiPiro JT, Talbert RL, Yee GC, Matzke GR, Wells BG \& Posey LM (Editors), Pharmacotherapy - A Pathophysiological Approach. 3rd edn. Appleton \& Lange, Stamford, UK.

5. Thurkauf A, Yuan J, Chen X et al. (1997). 2-Phenyl-4(5)-[[4-(pyrimidin2-yl)piperazin-1-yl]methyl]imidazole. A highly selective antagonist at cloned human D-4 receptors. Journal of Medicinal Chemistry, 40: 1 3.

6. Kulagowski JJ, Broughton HB, Curtis NR et al. (1996). 3-[[4-(4Chlorophenyl)piperazin-1-yl]-methyl]-1 H-pyrrolo[2,3-b]pyridine: An antagonist with high affinity and selectivity for the human dopamine $\mathrm{D}_{4}$ receptor. Journal of Medicinal Chemistry, 39: 1941-1942.

7. Carlini EA (1973). Farmacologia Prática sem Aparelhagens. Sarvier, São Paulo, SP, Brazil.

8. Verma A \& Kulkarni SK (1993). Differential role of dopamine receptor subtypes in thermoregulation and stereotypic behavior in naive and reserpinized rats. Archives Internationales de Pharmacodynamie et de Therapie, 324: 17-32.

9. Moore NC \& Gershon S (1989). Which atypical antipsychotics are identified by screening tests? Clinical Neuropharmacology, 12: 167184.

10. Sanberg PR, Bunsey MD, Giordano M \& Norman A (1988). The catalepsy test: its ups and downs. Behavioral Neuroscience, 102: 748-759.
11. Weiss JM \& Kilts CD (1998). Animal models of depression and schizophrenia. In: Schatzberg AF \& Nemeroff CB (Editors). Textbook of Psychopharmacology. American Psychiatric Press, Washington, DC, USA.

12. Wadenberg M-LG, Soliman A, VanderSpek SC \& Kapur S (2001). Dopamine $D_{2}$ receptor occupancy is a common mechanism underlying animal models of antipsychotics and their clinical effects. Neuropsycopharmacology, 25: 633-641.

13. Salmi $P$, Jimenez $P$ \& Ahlenius $S$ (1993). Evidence for specific involvement of dopamine $D_{1}$ and $D_{2}$ receptors in the regulation of body temperature in the rat. European Journal of Pharmacology, 236: 395-400

14. Puech AJ, Frances H \& Simon P (1978). Imipramine antagonism of apomorphine-induced hypothermia: A non-dopaminergic interaction. European Journal of Pharmacology, 47: 125-127.

15. Menon MK, Gordon LI, Kodama CK \& Fitten J (1988). Influence of $D_{1}$ receptor system on the $D_{2}$-mediated hypothermic response in mice. Life Sciences, 43: 871-881.

16. Salmi $P$ (1998). Independent roles of dopamine $D_{1}$ and $D_{2 / 3}$ receptors in rat thermoregulation. Brain Research, 781: 188-193.

17. Salmi $P$ \& Ahlenius $S$ (1998). Evidence for functional interactions between $5-\mathrm{HT}_{1} \mathrm{~A}$ and $5-\mathrm{HT}_{2 \mathrm{~A}}$ receptors in rat thermoregulatory mechanisms. Pharmacology and Toxicology, 82: 122-127.

18. Yamada J, Sugimoto $Y$ \& Horisaka K (1995). Serotonin $2\left(5-\mathrm{HT}_{2}\right)$ receptor agonist 1(2,5-dimethoxy-4-iodophenyl)-2-aminopropane (DOI) inhibits chlopromazine-induced and haloperidol-induced hypothermia in mice. Biological and Pharmaceutical Bulletin, 18: 15801583.

19. Salmi $\mathrm{P}$, Karlsson T \& Ahlenius $\mathrm{S}$ (1994). Antagonism by SCH23390 of clozapine-induced hypothermia in the rat. European Journal of Pharmacology, 253: 67-73.

20. Salmi P \& Ahlenius S (1996). Further evidence for clozapine as a dopamine $D_{1}$ receptor agonist. European Journal of Pharmacology, 307: 27-31. 